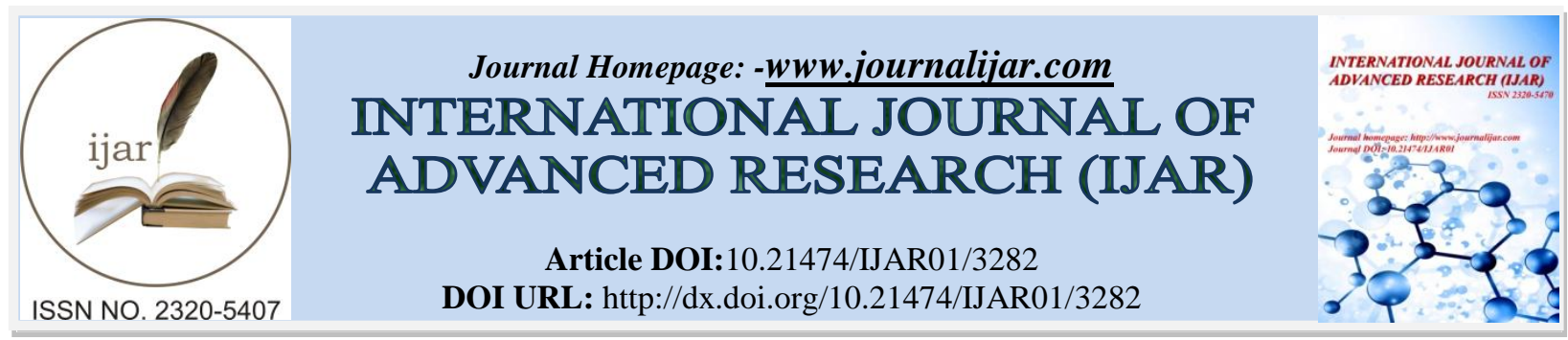

RESEARCH ARTICLE

\title{
OCCUPATIONAL NOSOCOMIAL SKIN INFECTIONS AMONG NURSING STAFF IN BAQUBAH TEACHING HOSPITALS.
}

Dr. Shahab Ahmed Shakir Al-Azzawi.

(M. B. Ch. B, D. C. M, F. I. B. M. S. Occupational \& Environmental Medicine), Assistant Professor, Department of Family and Community Medicine, Medical College, University of Diyala, Iraq.

\section{Manuscript Info}

Manuscript History

Received: 11 December 2016

Final Accepted: 05 January 2017

Published: February 2017

Key words:-

Occupational,Nosocomialskin infections,

Prevalence, Nursing staff

\section{Abstract}

Background:Health care workers especially nursing staff are at risk of acquiringnosocomial skin infections through occupational exposure.Nosocomial skin infections(NCSI)can be caused by viruses, bacteria, fungi and parasite.

Aims:To determine the prevalence of occupational nosocomial skin infections among the nursing staff in Baqubah teaching hospitals and to assess the factors responsible fornon-compliance of infection control measures amongst nursing staff.

Patients and Methods: A cross sectional study was conducted among nurses in two teaching hospitals in Baqubah cityfrom $1^{\text {st }}$ September 2015 to $31^{\text {th }}$ of March 2016.Special questionnaires were used to determine the prevalence of nosocomial skin infections among 200 nurses who worked at the twohospitals were chosen randomly, anddermatological examination was performed by dermatological specialist. $\mathrm{p}<0.05$ was considered statistically significant.

Results: The prevalence of occupational nosocomial skin infections was (53/200) (26.5\%) and it was most common in Baqubah teaching hospital; (68\%) in medical ICU and (64\%) in surgical departments. The majority of cases were infected with scabies (73.5\%), other infections;fungal infection (15\%), while pediculosis, warts, molluscumcontagiosum each one compose (4\%) of infections.High prevalence was among males (62\%), with age group more than 35 years old $(47 \%)$, with bad hand hygiene $(41 \%)$.

Conclusions:We conclude that scabies were the most common occupational nosocomial skin infections among the male nursing staff with age group more than 35 years old, with bad hand hygiene, working in Baqubah teaching hospital.

Copy Right, IJAR, 2017,. All rights reserved.

\section{Introduction:-}

Nosocomial infections, orhospital-acquired infections are those infectionsacquired in hospital or healthcare service unit, that first appear 48 hours or more after hospitaladmission or within 30 days after dischargefollowing in patient care. The Nosocomial infectionstransmitted byfivemain routes which includes; contact,droplet, airborne, common vehicle and vectorborne. [1].

Corresponding Author:-Shahab Ahmed Shakir Al-Azzawi.

Address:-(M. B. Ch. B, D. C. M, F. I. B. M. S. Occupational \& Environmental Medicine), Assistant

Professor, Department of Family and Community Medicine, Medical College, University of Diyala, Iraq. 
Medical staff movefrom patient to patient thus providing a way forpathogens to spread, inadequate sanitationprotocols regarding uniforms, equipmentsterilization, washing and other preventivemeasures that may either be unheeded byhospital personnel or too lax to sufficientlyisolate patients from infectious agents and lastlythe routine use of anti-microbial agents inhospitals creates selection pressure for theemergence of the resistant strains ofmicroorganisms. They are unrelatedto the original illness that brings patients to thehospital and neither present nor incubating as atthe time of admission. [2,3].

Nosocomial infections are classified as infections that are associated with the delivery of health care services in a health care facility. Nosocomial microorganisms may also be acquired by healthpersonnel working in the facility and can cause significant illness and time loss fromwork [4].

Nosocomial infection continues to be burden to the world health care system through increased risk to patients and employees. These infections have tremendous health and financial costs with an estimate incidence of 2,000,000 infection per year, 20.000 death per year and added costs of billion dollars per year. Effective infection control program are essential to controlling and preventing Nosocomial infection $[5,6]$.

\section{Aims:-}

To determine the prevalence of occupational nosocomial skin infections among the nursing staff in Baqubah teaching hospitals and to assess the factors responsible for non-complianceof infection control measures amongst nursing staff.

\section{Patients and Methods:-}

Across-sectional study was carried out at two teachinghospitals in Baqubahcity ( Baqubah and $\mathrm{Al}-\mathrm{Batool}$ teaching hospitals) over a period from $1^{\text {st }}$ September 2015 to $31^{\text {th }}$ of March 2016. Special questionnaires were used to determine the prevalence of nosocomial skin infections among 200 nurses who worked at the two hospitals were chosen randomly, The questionnaires were administered by using face-to-face interviews, The questionnaires was designed and constructed by the researcher including (occupational anddemographic variables; age, gender, departments, uses of personal protective measures, hand hygiene, risk factors of nosocomial skin infections) and dermatological examination was performed by dermatological specialist.To describe and analyze the findings of the study, the statistical means used were: Mean, Frequency and percentage as descriptive statistic and Chi-square as inferential statistic, All data were recorded and analyzed using SPSS 20, and p $<0.05$ was considered statistically significant.

\section{Results:-}

The prevalence of occupational nosocomial skin infections was (53/200) $(26.5 \%)$ and it was most common in Baqubah teaching hospital (68\%) in medical ICU and (64\%) in surgical departments. The majority of cases were infected with scabies (73.5\%), other infections; fungal infection (15\%), while pediculosis, warts, molluscumcontagiosum each one compose (4\%) of infections. High prevalencewas among males (62\%), with age group more than 35 years old (47\%), with bad hand hygiene (41\%).

Table 1 shows that the higherpercentage of nosocomial skin infections were among males $(62 \%)$ and $(85 \%)$ of them in Baqubah teaching hospital and $(15 \%)$ of them were in Al- Batool teaching hospital, while the female compose $(38 \%)$.This result was statically highly significant $(\mathrm{p}<0.001)$.

Table 1:- Distribution of Nosocomial skin infections (NCSI) in the two hospitals according to the gender.

\begin{tabular}{|c|c|c|c|c|c|c|c|}
\hline \multirow{3}{*}{ Gender } & \multicolumn{4}{|c|}{ Name of hospital } & \multirow{2}{*}{\multicolumn{2}{|c|}{ Total }} & \multirow[b]{2}{*}{ P-value } \\
\hline & \multicolumn{2}{|c|}{ Al-Batool } & \multicolumn{2}{|c|}{ Baqubah } & & & \\
\hline & $\mathrm{No}$ & $\%$ & $\mathrm{No}$ & $\%$ & $\mathrm{No}$ & $\%$ & \\
\hline Male & 5 & $15 \%$ & 28 & $85 \%$ & 33 & $62 \%$ & \\
\hline Female & 12 & $60 \%$ & 8 & $40 \%$ & 20 & $38 \%$ & \\
\hline Total & 17 & $32 \%$ & 36 & $68 \%$ & 53 & $100 \%$ & $p<0.001(H S)$ \\
\hline
\end{tabular}

$d f=1$, cal $\chi 2=37.72$, tab $\chi 2=3.841, P=<0.001$, which is highly significant 
Table 2 shows that the percentage of NCSI is higher in the age group more than 35 years old(47\%), the result was statically highly significant $(p<0.001)$.

Table 2:- Distribution of Nosocomial skin infections (NCSI) according to the age.

\begin{tabular}{|c|c|c|c|c|c|c|c|}
\hline \multirow{3}{*}{ Age } & \multicolumn{4}{|c|}{ NCSI } & & & \multirow{3}{*}{ p-value } \\
\hline & \multicolumn{2}{|c|}{ Yes } & \multicolumn{2}{|l|}{$\mathrm{NO}$} & \multicolumn{2}{|c|}{ Total } & \\
\hline & No & $\%$ & No & $\%$ & No & $\%$ & \\
\hline$<25$ yrs & 5 & $10 \%$ & 47 & $90 \%$ & 52 & $26 \%$ & \\
\hline $26-30$ & 18 & $35 \%$ & 33 & $65 \%$ & 51 & $25.5 \%$ & \\
\hline 31-35 & 8 & $16 \%$ & 42 & $84 \%$ & 50 & $25 \%$ & \\
\hline$>35$ & 22 & $47 \%$ & 25 & $53 \%$ & 47 & $23.5 \%$ & $\mathrm{p}<0.001(\mathrm{HS})$ \\
\hline Total & 53 & $26.5 \%$ & 147 & $73.5 \%$ & 200 & $100 \%$ & \\
\hline
\end{tabular}

$\mathrm{df}=3$, cal $\chi 2=20.485$, tab $\chi 2=3.815, \mathrm{P}=<0.001$, which is highly significant

Table 3 show that the prevalence of nosocomial skin infections (53/200) was (26.5\%) with high prevalenceof scabies (39/53)was (73.5\%) and more in medical ICU(68\%) and surgery (64\%) departments; other infections (15\%) fungal infection, while pediculosis, warts, molluscumcontagiousum each one compose (4\%).

Table 3 : Distribution of Nosocomial skin infections (NCSI) according to the departments.

\begin{tabular}{|c|c|c|c|c|c|c|c|c|c|c|c|c|}
\hline \multicolumn{13}{|c|}{ Types of NCSI } \\
\hline Department & \multicolumn{2}{|c|}{ Scabies } & \multicolumn{2}{|c|}{$\begin{array}{l}\text { Fungal } \\
\text { infection }\end{array}$} & \multicolumn{2}{|c|}{ Pediculosis } & \multicolumn{2}{|c|}{ Warts } & \multicolumn{2}{|c|}{$\begin{array}{l}\text { Molluscum } \\
\text { Contagiosum }\end{array}$} & \multicolumn{2}{|c|}{ Total } \\
\hline \multirow{2}{*}{$\begin{array}{l}\text { Medicine } \\
\text { ICU }\end{array}$} & No & $\%$ & No & $\%$ & No & $\%$ & No & $\%$ & No & $\%$ & No & $\%$ \\
\hline & 11 & $68 \%$ & 2 & 12.5 & 1 & 6 & I & I & 2 & 12.5 & 16 & 30 \\
\hline Surgery & 11 & $64 \%$ & 4 & 24 & 1 & 1 & 2 & 2 & I & I & 17 & 32 \\
\hline Gynecology & 5 & $100 \%$ & & & & & & & & & 5 & 10 \\
\hline Pediatric & 9 & $75 \%$ & 2 & 17 & 1 & 8 & / & I & / & / & 12 & 23 \\
\hline Orthopedic & 3 & $100 \%$ & & & & & & & & & 3 & 5 \\
\hline Total & 39 & $73.5 \%$ & 8 & $15 \%$ & 2 & $4 \%$ & 2 & $4 \%$ & 2 & $4 \%$ & 53 & $100 \%$ \\
\hline
\end{tabular}

Table 4 shows that the distribution of NCSI was (28\%) among those not using personal protective measures, the result was statically of no significant $(p>0.05)$.

Table 4: Distribution of Nosocomial skin infections (NCSI) according to the use of personal protective measures.

\begin{tabular}{|l|l|l|l|l|l|l|l|}
\hline \multirow{2}{*}{$\begin{array}{l}\text { Use of personal } \\
\text { protective } \\
\text { measures }\end{array}$} & \multicolumn{2}{|l|}{ NCSI } & NO & \multicolumn{2}{|l|}{ Total } & p-value \\
\cline { 2 - 8 } & YES & No & $\%$ & No & \% & No & \% \\
\hline USE & 3 & $15 \%$ & 17 & $85 \%$ & 20 & $10 \%$ \\
\hline \multirow{2}{*}{ NO USE } & 50 & $28 \%$ & 130 & $72 \%$ & 180 & $90 \%$ & p $>0.05(\mathrm{NS})$ \\
\hline Total & & & & & & & \\
\hline
\end{tabular}

$d f=1$, cal $\chi^{2}=1.1$, tab $\chi^{2}=3.841, \mathrm{P}>0.05$, which is of no significant

Table 5 shows that the distribution of NCSIwas (41\%) in those with bad hand hygieneand this result was statically of high significant $\mathrm{p}<0.0001$.

Table 5:- Distribution of Nosocomial skin infections(NCSI) according to hand hygiene.

\begin{tabular}{|c|c|c|c|c|c|c|c|}
\hline \multirow{3}{*}{$\begin{array}{l}\text { Hand } \\
\text { Hygiene }\end{array}$} & \multicolumn{4}{|c|}{ NCSI } & \multirow{2}{*}{\multicolumn{2}{|c|}{ Total }} & \multirow[b]{2}{*}{ p-value } \\
\hline & \multicolumn{2}{|c|}{ Yes } & \multicolumn{2}{|l|}{ NO } & & & \\
\hline & No & $\%$ & No & $\%$ & No & $\%$ & \multirow[b]{3}{*}{$\mathrm{p}<0.0001(\mathrm{HS})$} \\
\hline Good & 6 & $7 \%$ & 79 & $93 \%$ & 85 & $43 \%$ & \\
\hline Bad & 47 & $41 \%$ & 68 & $59 \%$ & 115 & $57 \%$ & \\
\hline Total & 53 & $26.5 \%$ & 147 & $73.5 \%$ & 200 & $100 \%$ & \\
\hline
\end{tabular}

$\mathrm{df}=1$, cal $\chi 2=111.07$, tab $\chi 2=3.841, \mathrm{P}=<0.0001$, which is highly significant 
Table 6 shows that (84\%) of cases of NCSI are among thoseworking overtime. This result was statically of no significant $(p>0.05)$.

Table 6 : Distribution of Nosocomial skin infections (NCSI) according to the risk factors.

\begin{tabular}{|c|c|c|c|c|c|c|c|c|c|}
\hline \multirow{3}{*}{ NCSI } & \multicolumn{6}{|c|}{ Presence of risk factor } & \multirow{2}{*}{\multicolumn{2}{|c|}{ Total }} & \multirow[b]{2}{*}{ P-value } \\
\hline & \multicolumn{2}{|c|}{ Chronic diseases } & \multicolumn{2}{|c|}{$\begin{array}{l}\text { working } \\
\text { overtime }\end{array}$} & \multicolumn{2}{|c|}{ Obesity } & & & \\
\hline & No & $\%$ & No & $\%$ & No & $\%$ & No & $\%$ & \\
\hline$Y E S$ & 1 & $2 \%$ & 36 & $84 \%$ & 6 & $14 \%$ & 43 & $36 \%$ & \\
\hline $\mathrm{NO}$ & 4 & $5 \%$ & 55 & $71 \%$ & 18 & $24 \%$ & 77 & $64 \%$ & \\
\hline Total & 5 & $4 \%$ & 91 & $76 \%$ & 24 & $20 \%$ & 120 & $100 \%$ & $P>0.05(N S)$ \\
\hline
\end{tabular}

$\mathrm{df}=2$, cal $\chi 2=2.186$, tab $\chi 2=5.991, \mathrm{P}>0.05$, which is of no significant

\section{Discussion:-}

This study showed that,The prevalence of nosocomial skin infections was $(26.5 \%)$ and it was most common in Baqubah teaching hospital (68\%). High percentage of cases were infected with scabies $(73.5 \%)$, mostlyamong males $(62 \%)$ and $(47 \%)$ of them were (>35) years old, with bad hand hygiene $(41 \%)$. This reflects obviously low awareness of health care, inappropriate and inadequate health services, bad sanitationof hospital environmentand bad nursing staff hygiene and not using personal protectivemeasures.

The result of this study shows that the prevalence of scabies $(73.5 \%)$ was high,which agree with other studies done in Canada, 25\% reported cases of scabies among their residents during a 1-year period [7]. Over a 1-year period, $17 \%$ of Michigan's nursing homes reported scabies in the facility.In Oslo, Norway three scabies outbreaks occurred in three nursing homes over a period of 6 months [8]. The close contact between staff and residents and between visitors and residents in nursing homes may contribute to a repetitive and prolonged duration of scabies outbreaks.[9-10].

In relation to gender, most of nurses in this study (62\%) were male; as the number of nursing staff (mainly of male gender) especially in the night shift, taking care of the patient unit or environment as an important aspect of patient care.This finding comes along with result obtained from study done in Baghdad[11].

The present study explores that high prevalence of hospital acquired skininfections were in medical ICU and surgical department more than other departments. This study agree with studies done in India, Serbia,Switzerland and Spain [12-15].

This study show that the prevalence of nosocomial skin infections was higher among the nursing staff not using the personal protective measures, disagree with the findings of a study done by Okechuku,in Nigeria which revealed that health care workers always used gloves when they anticipated contactwith body fluids, non-intact skin and mucus membranes[16].

The result on lack of knowledge of hand washing among nurses for the prevention of nosocomial skin infections. The above result agree with study conducted byIdang N. Ojonget al inNigeria[17].

This study shows the risk factors of nosocomial skin infection was not statistically significant,disagree with study done in Kampala, Uganda [18].

\section{Conclusions:-}

We conclude that scabies were the most common occupational nosocomial skin infections among the male nursing staffwith age group more than 35 years old, with bad hand hygiene, those working in Baqubah teaching hospital.

\section{Recommendations:-}

1. Training and re-training is necessary to increase nurses' knowledge toward nosocomial skin infections, immunization, improved hygiene, particularly hand washing. 
2. Infection control should beincorporated into the curriculum ofmedical/dental students, student nurses and otherparamedical.Enhance or develop the qualification of nursing staff.

3. further research in the health care providing especiallynursing staff are directed to prevent and control the acquisition of nosocomial skin infections.

\section{Acknowledgment:-}

Author acknowledge the cooperation of the nursing staff and thank DrNadhimKhazalNoamanfor data management support, quality check and analysis of data.

Conflicts of Interest: None.

\section{References:-}

1. Horan T.C, Gaynes R.P. Surveillance ofnosocomial infections. In: Hospitalepidemiology and infection control $3^{\text {rd }}$ ed., Mayhall C.G (ed).PhiladelphiaLippincortt. Williams andWilkins,2004: PP. 1659-1702.

2. Kozier, B.; Berman, A.; and snyder, S.; Fundamentals of Nursing: Person Education Limited, Infection Control and Asepsis, 2008, $7^{\text {th }}$ Edition, PP. 201-209.

3. Nosocomial infection. http:// en.wikipedia. org / wiki / nosoconial_infection. Retrieved 9th June,2009.

4. World Health Organization. Prevention of hospital acquired infections: A practical guide. Geneva: WHO. 2002.

5. Lewis, L.; Margaret, M.; Shannon, R.; Patricia G. Linda B.; Medical SurgicalNursing: Assessment and Management of Clinical Problems, Infection andHuman Immunodeficiency Virus Infection, 2007, ${ }^{\text {th }}$ Edition, Mosby, China,PP. 246- 247.

6. CDC, Center for Disease Control and Prevention, Healthcare-Associated Infections "HAIs", Atlanta, 2008, [http://www.cdc.gov/ncidod/dhqp/healthDis.htm], Article.

7. Vorou R, RemoudakiHD,Maltezou HC. Nosocomial scabies. J Hosp Infect 2007;65(1):9-14.

8. Heukelbach J, Feldmeier H. Scabies. Lancet 2006;367(9524):1767-74.

9. Holness DL, DeKoven JG, Nethercott JR. Scabies in chronic health care institutions. Arch Dermatol 1992;128(9):1257-60.

10. Andersen BM, Haugen H, Rasch M, et al. Outbreak of scabies in Norwegian nursing homes and home care patients: control and prevention. J Hosp Infect 2000;45(2):160-4.

11. Vincent J-L, Rello J, Marshall J, et al. International study ofHAI in ICU. JAMA 2009;302:2323-9.

12. Milena Ilić, LjiljanaMarković-DenićNosocomial infections prevalence study in a Serbian university Hospital Ilić M, Marković-DenićLj. Vojnosanit Pregl 2009; 66(11): 868-875.

13. Manuela Buehlmann, MD; Helmut Beltraminelli, MD; ChristophStrub, MD et al Scabies Outbreak in an Intensive Care Unit with 1,659 Exposed Individuals-Key Factors for Controlling the Outbreak Infect Control HospEpidemiol2009; 30:354-360.

14. Larrosa A, Cortes-Blanco M, Martinez S, et al. Nosocomial outbreak of scabies in a hospital in Spain. Euro Surveill 2003; 8:199-203.

15. Danchaivijitr S, Judaeng T, Sripalakij S, Naksawas K, PlipatT.Prevalence of nosocomial infection in Thailand 2006.J Med Assoc Thai. 2007; Aug;90(8):1524-9.

16. Okechuku E.F., et.al, (2012). Knowledge, practice of standard precautions in public health carefacilities, Abuja, Nigeria.Int J Infect Control 2012; v8:i3: Page 1 of 7.

17. Idang $\mathrm{N}$. Ojong et al. The practice of hand washing for the prevention of nosocomial infections among nurses in general hospital IkotEkpene, Akwalbom State, Nigeria. Arch. Appl. Sci. Res., 2014; 6 (1):97-101.

18. Caruso C. C., Bushnell T., Eggerth D., et al. Long working hours, safety, and health: toward a national research agenda. American Journal of Industrial Medicine. 2006;49(11):930-942. 